Wiesław Ostrowski

\title{
CONCEPT OF THE NEW TOPOGRAPHIC MAP OF POLAND AT THE SCALE OF 1:50 000
}

\begin{abstract}
The factual and technical foundations of the concept for the 1:50 000 topographic map published in Poland between 1995 and 2002 by the Head Office of Geodesy and Cartography are discussed in this article. While discussing content and graphic design, the author gives particular attention to the novel way of representing built-up areas.
\end{abstract}

Key words: topographic map, Poland.

\section{INTRODUCTION}

Published following World War II, Polish military topographic maps, as well as the civilian maps derived from them, were rendered in ways based mainly on specifications pertinent to Soviet military maps, the concept for which originated in the late 1930s. The content of the maps being published was chiefly suited to military needs.

The need to devise a new concept for the 1: 50000 topographic map was mainly the result of changes in the political system and constituted an opportunity for integrating original Polish and European contributions from the field of topographic cartography.

In the years 1992-1998, the concept of the 1: 50000 map was developed by a team of cartographers under the direction of the author of this article, at the initiative of the Surveyor General of Poland, R. Piotrowski. As early as in 1995, the first dozen sheets, covering Warsaw and its surroundings, were published. The development of the preliminary editing guidelines for the map, published in 1996 (Zasady redakcji..., 1996), was completed that same year. Their final, corrected and complete version was published in 1998 (Zasady redakcji..., 1998).

\section{THE FOUNDATIONS OF THE CONCEPT OF THE MAP}

The 1:50 000 map is a typical mid-scale topographic map. In comparison to a 1:10 000 map, some of its contents become significantly generalized. This primarily concerns all built-up areas. Apart from the built-up areas, other content elements also become generalized, but only to a slight degree, and a significant portion of the usual topographic information is retained. All in 
all however, the scale of 1:50 000 makes possible the clear and precise presentation of details that are essential for orientation in the field.

This essential attribute of the 1:50 000 map, with its capacity to cover a rather large area (over $300 \mathrm{~km}^{2}$ ) on one sheet, entails that the map can be used in various disciplines, and particularly:

- in administration and economic management, especially at the district level,

- in area planning at the regional level,

— in the preliminary planning of large-scale development projects,

- by tourists in the field,

- as the basis for the development of recreational trail maps,

- as an important tool in scientific research, particularly as the base for detailed thematic maps showing research results,

- as source material for the development of smaller-scale topographic and survey maps, as well as roadmaps.

For the development of the concept, the content and graphic form of available maps, originating from countries with old and well-developed cartographic traditions (Germany, Switzerland, the Netherlands, Belgium, France, Italy, Great Britain, Sweden and Finland), was analyzed. With regard to content, particular attention was given to those elements and pieces of information (e.g. technical road specifications) which, due to their classified nature, were missing from topographic maps published in Poland previously. Characterized by graphic precision and great clarity and readability, the tactical 1:100 000 map, as well as other Polish interwar maps, to some extent served as inspiration for certain graphic approaches. Despite its being outdated, following World War II, the surviving sheets of the tactical map were for many years used as the only available topographic maps. For a certain portion of the society, the traditions of the Polish interwar era's school of cartography did not fade into obscurity for this very reason. This was also due to the fact that certain symbols (representing e.g. roadside crosses, shrines, non-Christian temples, lodges, post offices and ranger stations) used on the interwar maps, were also used on recreational trail maps published by the Polish Cartographic Publishing House (PPWK).

\section{TECHNICAL SPECIFICATIONS AND THE REALIZATION OF THE CONCEPT OF THE MAP}

The first 48 sheets of the 1:50 000 map of the Mazowsze region were published in 1995, in accordance with "the 1942 system," which is based upon the Krasowski ellipsoid. All of the remaining sheets (including the subsequent 26 also published in 1995) were laid out in accordance with the new "1992 coordinate system", based on the GRS-80 ellipsoid.

In the years $1995-2002$, a total of 589 sheets were published, covering nearly $60 \%$ of Poland's surface area. (The country's entire area is covered by 1080 sheets - Fig. 1 The following numbers of sheets were published in each 


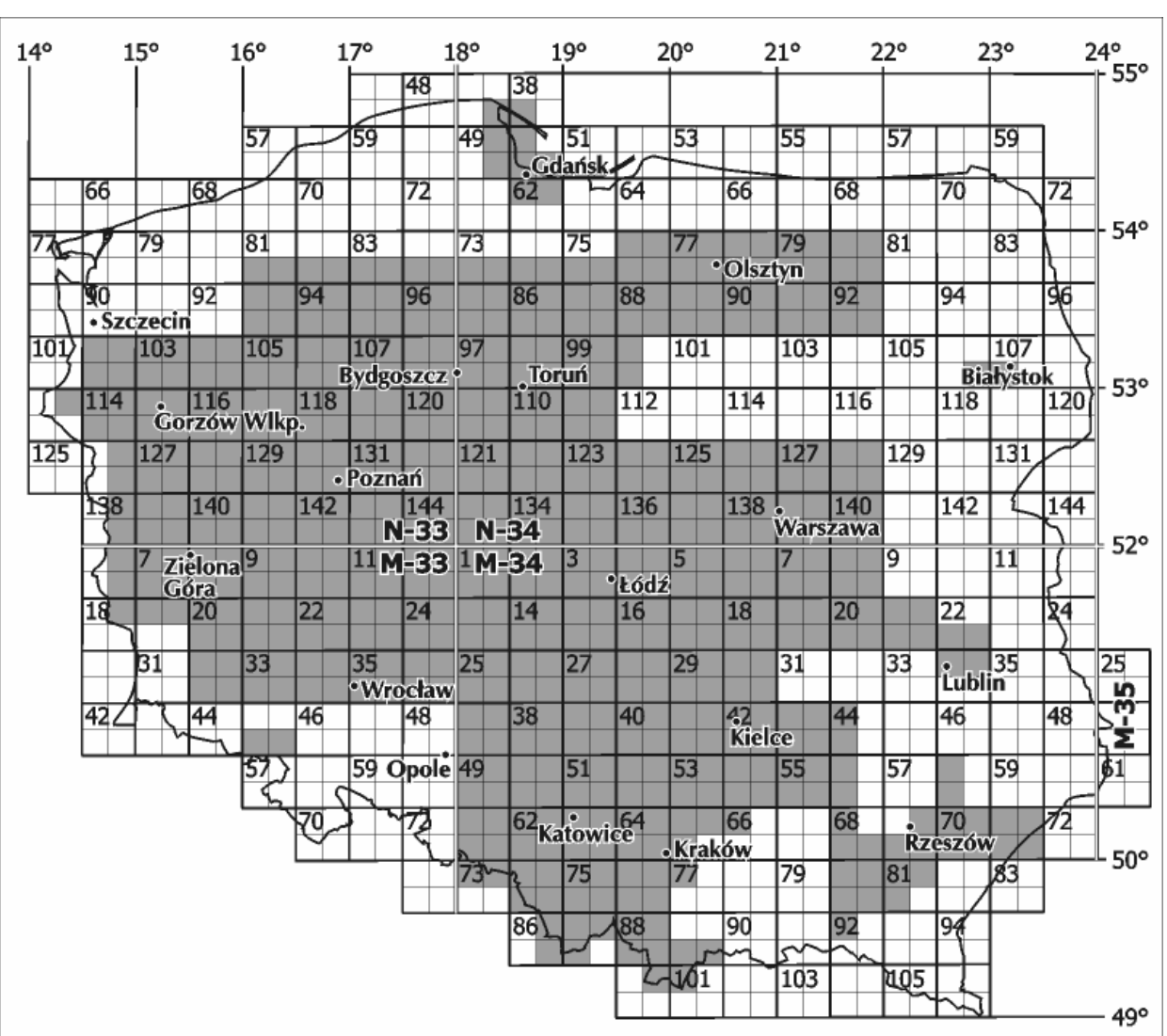

Fig. 1. The sheet index for the Topographic Map of Poland at 1:50 000, published in the years $1995-2002$.

year: 98 in 1995, 98 in 1996, 74 in 1997, 141 in 1998, 70 in 2000, 68 in 2001, and 64 in 2002). The map was printed on standardized sheets of paper with dimensions $580 \times 470 \mathrm{~mm}$. The basic edition consists of 1000 sheets, including 500 sheets folded in a hard cover to the dimensions of $116 \times 235 \mathrm{~mm}$. Maps representing larger cities and their surroundings (Warsaw, Kielce, Częstochowa, Katowice, Olsztyn, Poznań and Kraków), were published as comprehensive sheets, in the form of wall maps composed of nine standardized sheets.

It is notable that in contrast to the previous map of this scale, here explanations are provided for all the symbols and most of the abbreviations. It should be emphasized as well, that the symbol and abbreviation explanations are given in English (Fig. 2).

Six colors were used for the printing of the map:

- black (for the map border, the $1 \mathrm{~km}$ grid lines, public and industrial buildings, railroads, administrative boundaries, names and descriptions - with the exception of the names of bodies of water), 
— dark brown (for build-up areas and all other buildings, the outlines of roads and streets),

- blue (for bodies of water, isobaths, wetlands, the names and descriptions of bodies of water),

- green (for vegetation, cultivated areas and plantations, boundaries of national parks and nature reserves)

- red (for the shading of hard-surface roads and through streets),

- light brown (for contour lines and their descriptions, dikes, ridges, embankments, gorges, deforested mountain ranges and expanses of sand).

\section{THE CONTENT OF THE MAP}

The content of a map is influenced by its intended use and is limited with regard to graphic capacity, given the type of technical approach taken. Defining of the map's range of content was done with the presumption that the map is to be used as the base for geometric data used by geographic information systems. This justifies the omission of detailed, quantitative and qualitative object descriptions and thematic information, provided hitherto on military maps in particular.

One of the basic functions of the topographic map 1:50000 is to aid in orientation in the field. The choice of elements included is to a great degree governed by this function: the content elements represented are those that help in orientation, especially in areas where orientation may made be difficult. This is first and foremost in forested areas, where the roads, main paths, plot boundary lines and forest plot numbers are the chief elements used for orientation. Orientation is also made difficult in uniformly built-up areas, and can be made easier thanks to a representation of the entire network of streets with street classification, as well as of characteristic buildings and structures, gaps in the built environment, and the location of specific elements such as roundabouts and larger parking lots.

The 1:50 000 map is a comprehensive source of information regarding the terrain, including information that serves as the basis for administrative, economic, planning and scientific decisions, among others. For this reason, not only is the representation of individual objects significant, but so is the inclusion of general information such as for example regarding the type and extent of development in individual areas.

An attempt was made to represent, in a reasonably pictorial and unambiguous way, the physiognomic variations occurring in the transformed (anthropogenic) landscape, as well as the natural landscape, which has undergone relatively few changes. A functional criterion was also applied. Specifying the function of the objects represented on the map is especially important for administrative/economic purposes, but can also be significant for tourist use. 


\section{THE TRANSPORTATION NETWORK}

Eight categories of roads are recognized on the 1:50 000 map, the hierarchical classification of which is based on three technical criteria: the number of lines, the surface type and width. These technical parameters usually determine the functional categorization of the road. The functional criterion, along with the criteria of road density and length, was taken into account during the quantitative generalization of the two lowest classes of surface roads - namely field and forest cart roads and paths. The roads which are represented on the map have to lead to important objects that are present in the field and designated on the map; chiefly to individual farms and houses. For each road, an additional generalization criterion was its significance for orientation in the field, which is why in forested areas the graphic representation of the road system is more detailed than in agricultural areas.

Railroad classification was carried out based on three criteria: the width of the tracks, the number of tracks and the type of traction used. Furthermore, inoperative and no longer used railroads were designated pictorially.

City tramlines were included only if they could be shown in a clear manner - the line must run either far away from the street, along the side of the street, or down the middle of a street which is at least $0.6 \mathrm{~mm}$ wide on the map. On some sheets published after 1997, designated tourist trails are marked and the standard denotation of border crossings is introduced. Considering once again how the map can be of use to tourists, the inclusion of tourist trails increases the extent of the map's usefulness. On the other hand however, trail designation is traditionally considered to be part of the thematic, not the topographic, content of the map.

\section{DWELLINGS, BUILDINGS AND STRUCTURES}

As far as the representation of the dwellings on the 1:50 000 map is concerned, an entirely new concept was developed, incorporating initially agreed upon specifications for the design and the optimization the map. As it has already been mentioned, users working in administration, economics and area planning are primarily interested in knowing the extent to which a given area is developed and its function, while to be suitable for use in the field, a map has to first of all illustrate the physiognomic characteristics of the landscape. This pertains to built-up areas as well. Their typology is thus based on a functional criterion on the one hand, and on a physiognomic one on the other.

The system used to devise and represent buildings and built-up areas consists of four basic function categories:

- areas with domination of housing buildings (housing, with a high ratio of farm buildings),

- government buildings,

— industrial buildings, 
- other non-housing building complexes located outside of residential built-up areas; summer-home and trailer-home complexes.

The built environment's physiognomy and degree of development is most strongly correlated with its other features in the case of the first and mostoften encountered type of dwellings (housing and farm). The degree of development and the characteristics of the housing and farm built-up areas chiefly depend on its density and the size of the buildings.

In accordance with the criterion of density, three types of residential built environments are distinguished on the map:

- compact housing areas (with buildings comprising over $70 \%$ of the area's surface),

- dense housing area (with residential buildings being less than $30 \mathrm{~m}$ apart from each other)

- loosely overbuilt areas (with residential buildings being more than $30 \mathrm{~m}$ apart, in principle).

The first two types of dwellings are depicted as build-up areas (in two shades of brown), where only government buildings can be distinguished from the brown background. The loosely overbuilt areas are depicted by symbols representing individual buildings or farms.

With regard to the elevation and the expansiveness of the buildings, residential built-up areas can be divided into two basic categories:

- multi family dwellings (predominantly high or medium in elevation),

- single family dwellings (generally low in elevation).

Hitherto, on both Polish and foreign maps of this scale, no distinction was made between these two types of built environment, although the difference is especially significant in urban areas, because there, besides the density of the built environment, it is the other factor determining how the physiognomy of individual sections of the city is to be portrayed.

On the map, it is possible to completely and unambiguously distinguish the sparse multi family and single family housing from the compact housing areas (always shown as multi family, according to the established system) and dense housing areas (with housing buildings being less than $30 \mathrm{~m}$ apart). Unlike the usually occurring dense single familydwellings, the dense multi family dwellings take up relatively little space and are most often situated in central sections of larger cities. This is while the dominating type of multi family dwelligs in Poland is the multi family high-rise housing complex, which can be represented on the map with symbols standing for individual buildings. Sparse multi family and single family housing areas can usually be distinguished from each other based on the size of these symbols.

Government buildings of particular importance (which are often physiognomically striking as well) are represented by symbols or shown in top view. Other factors taken into account in the selection of the buildings to be shown, were: their usefulness in orientation - as points of reference (this being the result of their large size in relation to other buildings), and (in the case of freestanding buildings) their topographic situation. 
The surface marking of industrial/storage zones (in a light violet hue) makes it possible to distinguish areas occupied by industrial plants, cargo bases, depots and warehouses. In industrial zones marked in such a way, all of the buildings (including non-industrial ones), are represented as industrial buildings (in dark grey).

Explicatory abbreviations are printed next to government buildings and next to structures in the designated industrial/storage zones, describing a building's function or the type of industry housed there. Space allowing, the proper names of the larger or more important structures are used, especially in the case of those located outside urban districts. From a geographer's point of view, the consistent inclusion of explicatory abbreviations is an important attribute of the new map. In this respect, it is highly more detailed than a military map.

\section{OTHER ELEMENTS INCLUDED ON THE MAP}

In comparison to the representation of the overbuilt areas, changes in the representation and generalization of other elements are decidedly less extensive. A variable pattern was applied to distinguish areas of decidous, coniferous and mixed forest. The minimal surface area requirement for small vegetated or cultivated areas represented on the map has been lowered significantly. It is lower for those areas of vegetated land, which can be clearly distinguished from the rest of the landscape (orchards $-2 \mathrm{~mm}^{2}$ on the map, forests and areas of dense undergrowth $-4 \mathrm{~mm}^{2}$ ), and higher for the remaining types of land (grassland, wasteland $-10 \mathrm{~mm}^{2}$ ).

Throughout the entire mapped area of Poland, with the exception of two Tatra Mountain sheets, sloping terrain is traversed by one primary contour line every 10 vertical meters. In accordance with tradition, every fifth contour line (every 50 vertical meters) is thickened, but only up to the elevation of 400 meters above sea level. Above that elevation, in mid-altitude mountains, every tenth contour line is thickened, what does not obscure the rich orientational content (particularly the road system and the built environment) present in these regions.

\section{THE GRAPHIC DESIGN OF THE MAP}

By using a graphic design appropriate for the individual content elements, an attempt was made to optimally illustrate the physiognomic and functional properties of the landscape and of the individual objects constituting it, while simultaneously ensuring the readability, clarity and aesthetic quality of the map.

To attain the best possible graphic representation of the terrain, the following steps were taken:

1. A greater variety of colors was used with greater consistency to differentiate the content categories. 
2. New emblematic patterns were used.

3. A hierarchy of symbols was used, based on the significance (importance) of the objects being represented by them.

4. A greater variety of pictorial symbols was used.

The first two measures taken, particularly improved the map's graphic appearance. The individual content categories were assigned appropriate colors: vegetated, cultivated and protected areas (as well as symbols representing point and line objects) - green, bodies of water - blue, surface relief - light brown. The use of denser and more subtle emblematic patterns to represent certain categories of vegetation cover and cultivated areas made it possible to significantly lower the minimal surface area requirement for areas which can be represented in a contoured fashion, while also making their representation more precise (Fig 2).

The novel use of dark brown for the majority of the orientational elements, significantly freed up the map and also essentially expanded its informational capacity, what then made it possible to truly single out and bring out public and industrial buildings and other distinctive structures, presented as either solid black elements or elements filled in with a black crisscross pattern. Owing to this fact, the explicatory abbreviations printed next to the symbols for public buildings and industrial plants can be unambiguously matched up with the individual structures, what is especially significant in urban areas.

\section{CONCLUSION}

The evaluation of the 1:50 000 map was carried out in 1996 , at the $23^{\text {rd }}$ Polish Cartographic Conference, even before the final editing guidelines were published. It was expressed that by this interesting and highly successful undertaking (also including the creation of the new 1:10 000 map), a new chapter in the history of Polish topographic cartography was begun (Stankiewicz, 1996). In praise of the authors' concept for the map, the team which had worked on developing the concept received the Internal Affairs and Administration Minister's Award of the Second Degree, for their "outstanding creative achievements in architecture, building development, geodesy and cartography" (Siwek, 2001).

Considering the new formulation of the concept for the 1:50 000 map from a wider, historical perspective, one can see that the map's creation constitutes a turning-point in the nearly 200 years of Polish topographic cartography, since it is the first Polish concept for a civilian-use, medium-scaled topographic map, which takes into account the diverse needs of users and the various ways of utilizing the map, while at the same time, as has been stated by Remigiusz Piotrowski, the initiator of the development of this map, it is the carrier of a national tradition of aesthetic preferences and means of graphic expression (Program wydawniczy..., 1999). The previous two original Polish realizations of topographic maps had been done by the military 
and were suited primarily to military needs: the Polish Military's General Quartermaster's map (a project that was halted at the outbreak of the November Uprising in 1830 and completed by the Russians in 1843), as well as the maps created during the interwar years by the Military Geographical Institute.

Taking into account the circumstances outlined above and the generally positive reviews of the new 1:50 000 map, it is not surprising that the cartographic community was taken aback by the decision to halt the publication of this map at a time when around $60 \%$ of Poland's territory had already been covered by it, and to replace it with a military map created with V Map Level 2 technology, in accordance with the UTM coordinate system, which is the NATO standard. This decision came in association with significant reorganization of the Polish Head Office of Geodesy and Cartography.

The decision was criticized at the Association of Polish Cartographers' first conference, which took place in Wrocław, from the $21^{\text {st }}$ to the $23^{\text {rd }}$ of November in 2002. The Surveyor General of Poland defended the decision by citing highly limited budget resources, which were preventing the Head Office of Geodesy and Cartography from carrying out its tasks. The unanimous opinion of the conference participants forced the Surveyor General to pledge that, financial resources allowing, after the completed publication of the military map (what is to occur within two years), the publication of the civilian map being discussed is to be completed as well. Let us hope that arguments supporting such a resolution, including the higher quality and precision of the civilian map in comparison to the military map, as well as the need to maintain the uniformity of concepts for the 1:50 000 and 1:10 000 maps, are significant enough to outweigh financial considerations, and that after some time has passed, the undertaking which was initiated ten years ago, and has advanced so significantly, will finally be completed.

\section{REFERENCES}

Grygorenko W., 1991, Kartografia polska w latach 1945-1990 w potrzasku reorganizacji i cenzury [Polish Cartography from 1945 to 1990: Ensnared by Reorganization and Censorship; in Polish], Polski Przegl. Kartogr., V, 23, no. 1-2, 1-7.

Ostrowski W., 2000, Koncepcja nowej mapy topograficznej Polski w skali 1:10 000. [The Concept for the New Topographic Map of Poland at the Scale of 1:50 000; in Polish], Polski Przegl. Kartogr., vol. 32, no. 3, 188-197.

Ostrowski W., 1996, Izobrazheniye gorodow na nowykh polskikh topograficheskikh kartakh [The Representation of Cities on New Polish Topographical Maps; in Russian], Geod. $i$ Kartogr., no. 1, 44-46.

Ostrowski W., 1997, New Polish Topographic Maps and Geographers. Requirements, Acta Universitatis Carolinae Geographica, Supplementum", 512-554.

Ostrowski W., Stankiewicz M., 1999, The New generation of Polish topographic maps, The Polish Cartography, $129-137$.

Program wydawniczy Stużby Geodezyjnej i Kartograficznej RP [The Polish Geodetic and Cartographic Service's Publication Program; in Polish], 1999, The Head Office of Geodesy and Cartography, Warsaw. 
Siw ek J., 2001, Nagroda Ministra Rozwoju Regionalnego i Budownictwa oraz Ministra Spraw Wewnętrznych i Administracji za opracowanie koncepcji cywilnej mapy topograficznej w skali 1:50 000 [The Regional and Building Development Minister's and the Internal Affairs and Administration Minister's Award for the Development of the Concept for a Civilian-use Topographic Map at the Scale of 1:50 000; in Polish], Polski Przegl. Kartogr., vol. 33, no. 1, 78-79.

Stankiewicz M., 1996, Ocena zakresu treści, formy graficznej i redakcji nowej edycji map topograficznych 1:10 000 i 1:50 000 [Evaluation of the Content, Graphic Design and Editing of New Edition 1:10 000 and 1:50 000 Topographic Maps; in Polish], [in:] Polska kartografia lat 90-tych, Materiaty Ogólnopolskich Konferencji Kartograficznych , vol. 18, Warsaw, 12-26.

Stankiewicz M., Głażewski A., 2000, Współczesne mapy topograficzne w wersji cywilnej [Civilian Versions of Modern Topographic Maps; in Polish], [in:] Kartografia polska u progu XXI wieku. XXVII Ogólnopolska Konferencja Kartograficzna, Warszawa, December 8-9, 2000, Materiały Ogólnopolskich Konferencji Kartograficznych, vol. 22, Warszawa, 7-32.

Zasady redakcji mapy topograficznej w skali 1:50 000. Katalog znaków. Instrukcja techniczna, 1996, Ministerstwo Gospodarki Przestrzennej i Budownictwa, Główny Geodeta Kraju. Państwowa Służba Geodezyjna i Kartograficzna [Editing Guidelines for Topographic Maps at the scale of 1:50 000. A Catalogue of Symbols. Technical Guidelines, 1996. The Ministry of Area Management and Building Development, Surveyor General of Poland. Polish Geodetic and Cartographic Service; in Polish], Warszawa.

Zasady redakcji mapy topograficznej $w$ skali 1:50 000. Katalog znaków. Instrukcja techniczna, 1998, wyd. II poprawione. Główny Geodeta Kraju. Główny Urząd Geodezji i Kartografii [Editing Guidelines for Topographic Maps at the scale of 1:50 000. A Catalogue of Symbols. Technical Guidelines, 1998. 2nd and rev. ed., Surveyor General of Poland. The Head Office of Geodesy and Cartography; in Polish], Warszawa.

English translation: Joanna M. Kwiatowska 